\title{
AKTIVITAS TABIR SURYA EKSTRAK RIMPANG KUNYIT HITAM (Curcuma caesia) SECARA IN-VITRO
}

\author{
Fush Shilat Jibalathuull*, Jaka Fadraersada, Laode Rijai \\ Laboratorium Penelitian dan Pengembangan FARMAKA TROPIS, Fakultas \\ Farmasi Universitas Mulawarman, Samarinda, Kalimantan Timur \\ *Email :fush.kurniawan@gmail.com
}

\begin{abstract}
ABSTRAK
Curcuma caesia memiliki aktivitas antioksidan yang tinggi. Aktivitas antioksidan yang tinggi memiliki hubungan yang erat dengan aktivitas tabir surya. Tabir surya merupakan senyawa yang dapat digunakan untuk menyerap atau memantulkan sinar matahari sehingga dapat mencegah gangguan pada kulit. Penelitian ini bertujuan untuk mengetahui aktivitas dan potensi tabir surya dari kunyit hitam (Curcuma caesia). Metode yang digunakan dimulai dari pengumpulan sampel, ekstraksi dengan cara maserasi, dan pengujian tabir surya secara in-vitro dengan menggunakan spektrofotometer UV-Vis. Pengujian aktivitas tabir surya dilakukan dengan menggunakan variasi konsentrasi ekstrak sebesar 50 ppm, 100 ppm, 150 ppm, 200 ppm dan 250 ppm yang diukur pada panjang gelombang UV yaitu 292,5$372,5 \mathrm{~nm}$. Berdasarkan hasil pada penelitian, konsentrasi efektif ekstrak sebagai tabir surya yakni pada konsentrasi 150 ppm dengan \% Te sebesar 5,760 dan \% Tp sebesar 0,816 serta profil tabir surya ekstrak rimpang kunyit hitam yang diperoleh adalah \% Te termasuk dalam kategori proteksi ekstra sedangkan \% Tp termasuk dalam kategori sunblock.
\end{abstract}

Kata Kunci: Curcuma caesia, spektrofotometer UV-Vis, tabir surya, \%Te, \%Tp

\begin{abstract}
Curcuma caesia has high antioxidant activity. High antioxidant activity has a close relationship with sunscreen activity. Sunscreen is a compound that can be used to absorb or reflect sunlight so as to prevent skin disorders. This study aims to determine the activity and potential of sunblock from black turmeric (Curcuma caesia). The methods used were started from sample collection, extraction by maceration, and in vitro sunscreen testing using UV-Vis spectrophotometer. Testing of sunscreen activity was done by using variation of extract concentration by $50 \mathrm{ppm}, 100 \mathrm{ppm}, 150 \mathrm{ppm}, 200 \mathrm{ppm}$ and $250 \mathrm{ppm}$ measured at UV wavelength of 292,5-372,5 $\mathrm{nm}$. Based on the results of the study, the effective concentration of extract as sunscreen that is at concentration of $150 \mathrm{ppm}$ with \%Te of 5.760 and $\%$ Tp of 0.816 and sunscreen profile extract of black turmeric rimpang obtained is $\%$ Te included in the category of extra protection while \%Tp included in the category Sunblock..
\end{abstract}


Keywords: Curcuma caesia, UV-Vis spectrophotometer, sunscreen,\% Te,\% Tp

\section{PENDAHULUAN}

Penyinaran matahari yang singkat pada kulit dapat menyebabkan kerusakan epidermis sementara, gejalanya biasanya disebut sengatan surya. Sinar matahari dapat menyebabkan eritema ringan hingga luka bakar yang nyeri pada kasus yang lebih parah. Jika mengenai sebagian besar kulit dapat menyebabkan gejala demam, mual, muntah, menyebabkan terjadinya menggigil dan kadang-kadang menimbulkan rasa gatal (Depkes RI, 1985).

Tabir surya merupakan bahan-bahan kosmetik yang secara fisik atau kimia dapat menghambat penetrasi sinar UV ke dalam kulit. Bahan aktif yang digunakan sebagai tabir surya dibagi menjadi dua, yaitu tabir surya kimia dan tabir surya fisik. Tabir surya kimia bekerja dengan menyerap energy radiasi, sedangkan tabir surya fisik bekerja dengan memantulkan radiasi dan bersifat tidak tembus cahaya (Oroh dan Harun, 2001).

Berbagai jenis kunyit memiliki peran dan manfaat dalam dunia kesehatan. Sejak zaman dahulu kunyit dipercaya dapat menyembuhkan berbagai macam penyakit. Salah satu kunyit yang dapat membantu dalam pemeliharaan kesehatan adalah kunyit hitam (Curcuma caesia). Telah dilaporkan bahwa kunyit hitam (Curcuma caesia) memiliki berbagai macam kandungan fitokimia yaitu karbohidrat, protein, asam amino, steroid, glikosida, flavonoid, alkaloid dan tannin. Kunyit hitam (Curcuma caesia) memiliki kandungan fitokimia yang lebih tinggi dibandingkan dengan jenis kunyit yang lain (Rajeshwari, 2012).

Maserasi adalah proses perendaman sampel untuk menarik komponen yang diinginkan dengan kondisi dingin diskontinyu. Keuntungannya yakni lebih praktis, pelarut yang digunakan lebih sedikit, dan tidak memerlukan pemanasan, tetapi waktu yang dibutuhkan relatif lama (Agung dkk, 2014). Dalam proses maserasi, simplisia yang akan diekstraksi biasanya ditempatkan pada wadah atau bejana yang bermulut lebar bersama dengan pelarut yang telah ditetapkan, bejana ditutup rapat dan isinya dikocok berulang-ulang. Pengocokan memungkinkan pelarut segar 
mengalir berulang-ulang masuk ke seluruh simplisia yang sudah halus (Ansel, 1989).

Tujuan dari penelitian ini adalah untuk mengetahui aktivitas dan profil tabir surya ekstrak rimpang kunyit hitam (Curcuma caesia) dalam berbagai variasi konsentrasi yang dikategorikan sebagai tabir surya dan mengetahui konsentrasi efektif ektrsak rimpang kunyit hitam (Curcuma caesia) sebagai tabir surya.

\section{METODE PENELITIAN}

\section{Bahan}

Rimpang Kunyit Hitam (Curcuma caesia), Metanol.

\section{Peralatan}

Seperangkat alat maserasi, spektrofotometer UV-Vis, desikator, rotary evaporator, timbangan analitik.

\section{Prosedur}

\section{Penyiapan Sampel}

Sampel yang digunakan adalah rimpang kunyit hitam (Curcuma caesia) yang berasal dari kota Toraja. Setelah pengumpulan bahan, dilakukan sortasi basah dengan menyeleksi bagian tanaman yang tidak digunakan seperti kotoran dari luar. Kemudian ditimbang dan dicuci dengan air mengalir. Dirajang dan dikeringkan sampel dengan cara diangin-anginkan pada suhu kamar dan terlindung dari cahaya matahari. Dilakukan sortasi kering dengan cara menyeleksi pengotor yang mungkin terikut, lalu disimpan.

\section{Ekstraksi Sampel}

Simplisia rimpang kunyit hitam (Curcuma caesia) dimasukkan ke dalam wadah kaca (toples) kemudian diekstraksi dengan pelarut metanol sehingga diperoleh bagian residu dan bagian maserat. Proses maserasi dilakukan dalam wadah yang tertutup rapat (toples). Toples didiamkan selama 24 jam dengan sesekali diaduk. Proses maserasi diulangi beberapa kali sampai pelarut metanol berwarna jernih. Ekstrak kunyit hitam kemudian dipisahkan dari pelarut metanol menggunakan rotary evaporator sehingga diperoleh ekstrak kental. Ekstrak kental 
selanjutnya diuapkan diatas water bath untuk memperoleh ekstrak kering dan kasar rimpang kunyit hitam.

\section{Uji Aktivitas dan Kategori Tabir Surya}

Ekstrak kering yang dihasilkan dalam proses maserasi dibuat larutan stok dan dibuat variasi konsentrasi yakni 50, 100, 150, 200 dan 250 ppm dengan menggunakan pelarut metanol dan diukur serapannya sebanyak 3 replikasi dengan menggunakan spektrofotometer UV-Vis pada panjang gelombang yang dapat menimbulkan eritema dan pigmentasi yaitu 292,5-372,5 nm.

Aktivitas tabir surya ekstrak daun belimbing hutan ditentukan dengan analisis deskriptif berdasarkan hasil perhitungan nilai persen transmisi eritema (\% Te) dan transmisi pigmentasi (\% Tp) yang telah diperoleh. Kemudian, nilai \% Te dan $\%$ Tp dari tiap seri konsentrasi tersebut dan dikategorikan ke dalam penilaian aktivitas tabir surya yaitu sunblock, proteksi ekstrak, suntan standar atau fast tanning seperti yang terlihat pada Tabel 1.

Tabel 1. Profil Tabir Surya

\begin{tabular}{ccc}
\hline \multirow{2}{*}{ Kategori } & \multicolumn{2}{c}{ \% Transmisi } \\
\cline { 2 - 3 } & Eritema & Pigmentasi \\
\hline Sunblock & $<1 \%$ & $3-40 \%$ \\
\hline Proteksi Ekstra & $1-6 \%$ & $42-86 \%$ \\
\hline Suntan Standar & $6-12 \%$ & $45-86 \%$ \\
\hline Fast Tanning & $10-18 \%$ & $45-86 \%$ \\
\hline
\end{tabular}

\section{HASIL DAN PEMBAHASAN}

\section{Ekstraksi Rimpang Kunyit Hitam}

Rimpang kunyit hitam digunakan dalam penelitian ini dibuat dalam bentuk simplisia. Simplisia yang diperoleh dari sampel 2 kilo gram adalah 307 gram. Proses pembuatan simplisia rimpang kunyit hitam meliputi beberapa tahapan, yakni pengumpulan daun lalu diambil bagian daunnya, pencucian dan sortasi basah, pengeringan dan sortasi kering, serta simplisia dipotong kecil-kecil agar proses penarikan maksimal senyawa pada saat pembuatan ekstrak 
Simplisia yang didapatakan kemudian dimaserasi dengan pelarut metanol. Maserasi adalah proses penarikan senyawa yang terdapat dalam sampel dimana pelarut metanol berdifusi ke dalam dinding sel sampel. Metanol merupakan pelarut universal sehingga dapat menarik senyawa polar maupun non polar. Kemudian cairan ekstrak yang didapat dipekatkan dengan rotary evaporator, diuapkan di waterbath dan disimpan dalam desikator.

\section{Uji Aktivitas dan Profil Tabir Surya}

Pengujian aktivitas tabir surya dilakukan dengan membuat larutan stok dan variasi konsentrasi dari ekstrak rimpang kunyit hitam yaitu dengan membuat 5 konsentrasi dengan menggunakan pelarut metanol dengan masing-masing 3 replikasi. Masing-masing konsentrasi ekstrak rimpang kunyit hitam diukur serapannya dengan menggunakan spektrofotometer UV-Vis pada panjang gelombang yang dapat menimbulkan eritema dan pigmentasi yaitu 292,5-372,5 nm serta dibandingkan dengan blanko yaitu metanol.

Senyawa yang berpotensi menunjukkan aktivitas tabir surya yang baik adalah bahan yang dapat menghasilkan nilai \% Te ataupun \% Tp yang kecil dengan konsentrasi yang paling rendah. Hal ini menunjukkan bahwa, senyawa tersebut dapat menghalangi sinar UV melewati kulit sehingga dapat mencegah terjadinya kerusakan kulit akibat sinar matahari.

Hasil pengujian didapatkan nilai absorbansi yang kemudian digunakan untuk menghitung \% Te dan \% Tp sehingga dapat dilihat pada tabel 2.

Tabel 2. Uji aktivitas dan Kategori Tabir Surya Ekstrak Rimpang Kunyit Hitam

\begin{tabular}{ccccc}
\hline $\begin{array}{c}\text { Konsentrasi } \\
(\mathbf{p p m})\end{array}$ & \% Te & $\begin{array}{c}\text { Profil Tabir } \\
\text { Surya }\end{array}$ & \% Tp & $\begin{array}{c}\text { Profil Tabir } \\
\text { Surya }\end{array}$ \\
\hline 50 & 31,680 & - & 19,120 & Sunblock \\
100 & 11,669 & Suntan Standar & 3,100 & Sunblock \\
150 & 5,760 & Proteksi Ekstra & 0,816 & Sunblock \\
200 & 3,380 & Proteksi Ekstra & 0,350 & Sunblock \\
250 & 2,330 & Proteksi Ekstra & 0,002 & Sunblock \\
\hline
\end{tabular}

Hasil penelitian menunjukkan bahwa ekstrak rimpang kunyit hitam memiliki aktivitas tabir surya. Konsentrasi efektif ekstrak rimpang kunyit hitam sebagai tabir 
surya yaitu 150 ppm dengan \% Te sebesar 5,760 dan \% Tp sebesar 0,816 serta profil tabir surya ekstrak rimpang kunyit hitam yang diperoleh adalah \% Te termasuk dalam kategori proteksi ekstra sedangkan \% Tp termasuk dalam kategori sunblock.

\section{KESIMPULAN}

Pada penelitian ini didapatkan kesimpulan bahwa ekstrak rimpang kunyit hitam memiliki aktivitas sebagai tabir surya. Konsentrasi efektif ekstrak rimpang kunyt hitam sebagai tabir surya yaitu 150 ppm dengan \% Te sebesar 5,760 dan \%Tp sebesar 0,816 serta profil tabir surya ekstrak rimpang kunyit hitam yang diperoleh adalah \% Te termasuk dalam kategori proteksi ekstra sedangkan \% Tp termasuk dalam kategori sunblock.

\section{DAFTAR PUSTAKA}

Ansel, Howard C. 1989. Pengantar Bentuk Sediaan Farmasi Edisi Keempat (Terjemahan dari Introduction to Pharmaceutical Dosage Forms). Universitas Indonesia Press. Jakarta.

Agung A.B.P., Wayan N.B., Putu N.D., dan Luh N.U.S. 2014. Ekstraksi Zat Warna Alam Dari Bonggol Tanaman Pisang (Musa paradiasciaca L.) Dengan Metode Maserasi, Refluks, dan Sokletasi. Jurnal Kimia. Vol. 8, No. 1.

Depkes RI, 1985. Formularium Kosmetika Indonesia. Direktorat Jendral Pengawas Obat dan Makanan: Jakarta.

Oroh E., dan Harun E.S. 2001. Tabir Surya (Sunscreen). Berkala Ilmu Penyakit Kulit dan Kelamin. 13(1); 1. 